Door: Albert Colon (colona@kempenhaeghe.nl), neurologie, Academisch Centrum voor Epileptologie, Kempenhaeghe, Heeze, Pauly Ossenblok, biomedische technologie, Technische Universiteit Eindhoven, Nicole van Klink ${ }^{\mathrm{I}, 2}$ en Frans Leijten $^{\mathrm{I}}$ Ineurologie en neurochirurgie, Hersencentrum Rudolf Magnus, Universitair Medisch Centrum Utrecht

${ }^{2}$ Stichting Epilepsie Instellingen Nederland, Heemstede/Zwolle.

\title{
Multimodale beeldvorming voor effectieve epilepsiechirurgie
}

Wanneer een medicatieresistente patiënt wordt gezien als mogelijke kandidaat voor een operatie, wordt een reeks diagnostische onderzoeken ingezet. Over het algemeen is er al een MRI beschikbaar, evenals een routine-EEG. De eerste vervolgonderzoeken zullen een video-EEG aanvalsregistratie en een neuropsychologisch onderzoek zijn, soms gevolgd door een MEG-onderzoek, een PET, mogelijk een ictale SPECT en een simultaan EEG- en fMRI-onderzoek. Ook invasief onderzoek is voor een deel van de patiënten geïndiceerd. Op basis van deze onderzoeken kan er een operatiestrategie bepaald worden. Hiervoor is het niet alleen van belang dat er een duidelijke indicatie is van de locatie van het epileptogene hersengebied, maar ook van de relatie van dit gebied met omliggend hersenweefsel dat essentieel is voor functie. Dit gebied, bijvoorbeeld het motor- of taalgebied, kan onder andere in beeld gebracht worden met functioneel MRI (fMRI)-onderzoek.

Van elk van de bovengenoemde onderzoeken komt het verslag in eerste instantie bij de behandelaar terecht. Die wordt zo geconfronteerd met een diversiteit aan gegevens. Het resultaat wordt op papier aangeleverd, met een selectie van de afbeeldingen met daarin een indicatie van het gebied dat door het betreffende diagnostisch onderzoek wordt aangeduid als hét gebied dat mogelijk verantwoordelijk is voor de epilepsie van de patiënt. De behandelaar is voor het bepalen van de convergentie van de diverse afbeeldingen afhankelijk van zijn of haar visuele oordeel. Bovendien moet op basis van de verschillende verslagen en afbeeldingen een consistente casus worden voorbereid, die inzichtelijk gepresenteerd kan worden op een bespreking van de werkgroep epilepsiechirurgie. Tijdens een dergelijke bespreking wordt de operatiestrategie vastgesteld. Om dit proces te ondersteunen is in Kempenhaeghe software ontwikkeld die het mogelijk maakt om het resultaat van de boven genoemde onderzoeken samen te brengen in één afbeelding ten opzichte van de anatomie van de individuele patiënt. Dit is het softwarepakket 'Multi-modal Imaging for Neurological Diagnostics' (MIND) ${ }^{\mathrm{I}}$. Als de nietinvasieve preoperatieve onderzoeken onvoldoende uitsluitsel geven over de locatie van het epileptogene gebied wordt invasief onderzoek overwogen. Als het vermoeden bestaat dat de epilepsie wordt gegenereerd in diepgelegen anatomische structuren wordt gekozen voor een onderzoek met diepte-elektroden, het zogenaamde stereotactische EEG (stereo-EEG)-onderzoek. Er is in Kempenhaeghe een softwarepakket ontwikkeld, de Depth Electrode Navigator Software (DENS), dat ondersteuning biedt bij het herkennen van de diepte-elektroden op een post-implantatie-CT en het visualiseren hiervan ten opzichte van de anatomie van de individuele patiënt. In de eerste bijdrage van deze rubriek wordt de mogelijke toepassing besproken van deze software voor de diagnostiek en behandeling van patiënten die in aanmerking komen voor een operatie.

In het National Hospital for Neurology and Neurosurgery, Queen Square in Londen is gekozen voor een primair meer neurochirurgische benadering en gebruikt men computergesteunde planningssoftware om stereo-EEG te plannen, waarbij ook een driedimensionale (3D) representatie van het bloedvatenstelsel word toegevoegd aan het model. Deze software is onderdeel van het veel meer omvattende softwarepakket Epinav, dat is gericht op het creëren van multimodale patiënt-specifieke beelden om precieze intracraniale navigatie en chirurgie voor individuele patiënten te sturen. In de tweede bijdrage van deze rubriek worden twee cases besproken voor wie de resultaten van de verschillende onderzoeken, MEG, PET en subdurale elekrodegrids, werden geïntegreerd in een multimodaal model met behulp van Epinav. De multimodale beelden kunnen direct ingelezen worden in de neuronavigatie-systemen, die gebruikt worden door de neurochirurg om zich te oriënteren tijdens de operatie. Dit zal in de toekomst zijn invloed doen gelden op de praktijk van de functionele neurochirurgie en kan ook een rol gaan spelen bij bijvoorbeeld glioomoperaties waarbij epilepsie een probleem is.

${ }^{1}$ De MIND-software is ontwikkeld in het kader van een ECSEL Joint Undertaking project (projectnummer 692470), genaamd Advancing Smart Optical Imaging and Sensing for Health (ASTONISH).

${ }^{2}$ DENS is ontwikkeld in het kader van een ENIAC Joint Undertaking project (projectnummer 324257), genaamd Devices for Neuro-Control and NeuroRehabilitation (DeNeCor). 